ECCOMAS

Proceedia
COMPDYN 2021

$8^{\text {th }}$ ECCOMAS Thematic Conference on Computational Methods in Structural Dynamics and Earthquake Engineering

M. Papadrakakis, M. Fragiadakis (eds.)

\title{
IN PLANE BEHAVIOR OF PARTIALLY GROUTED MASONRY WALLS USING A NEW CLAY UNIT. LABORATORY MEASUREMENTS AND NUMERICAL SIMULATIONS
}

\author{
George C. Manos' ${ }^{1}$ Lazaros Melidis², Lampros Kotoulas³ ${ }^{3}$ Kostas Katakalos ${ }^{4}$ \\ ${ }^{1,2,3,4}$ Lab. Strength of Materials and Structures, Aristotle University
}

gcmanos@civil.auth.gr, lazmelidis@gmail.com, kotoulaslambros@gmail.com,kkatakal@civil.auth.gr

\begin{abstract}
A new innovative clay brick unit is used for the construction of partially grouted masonry walls. This new unit aims to provide both the required mechanical properties and thermal insulating properties. The behavior of masonry specimens constructed with this unit and thin mortar method under in plane loads is discussed here. The basic mechanical properties of the examined construction system are measured by a series of material tests, prism tests under combined shear and compression and wallets under compression tests. The laboratory measurements are compared with the defined by EC6 values. Following, diagonal compression tests were conducted at the Laboratory of Strength of Materials and Structures (Aristotle University of Thessaloniki) to ungrouted and grouted masonry wallets with different reinforcing details employing horizontal reinforcing steel bars placed at the prefabricated holes of the clay unit. The effect of the reinforcing steel bars in the bearing capacity and in the post peak behavior is investigated. Apart from the experimental investigation, numerical models simulating these tests were developed utilizing all the geometrical properties of the specimens and the mechanical properties of the materials used. The numerically simulated behavior resembles the measured load-deformation response of the tested specimens and the observed actual damage at the end of the tests.
\end{abstract}

Keywords: Partially grouted masonry, In plane behavior, Laboratory measurements, Numerical Simulations.

ISSN:2623-3347 @ 2021 The Authors. Published by Eccomas Proceedia.

Peer-review under responsibility of the organizing committee of COMPDYN 2021.

doi: 10.7712/120121.8682.19496 


\section{INTRODUCTION}

The vulnerability of unreinforced masonry walls subjected to seismic loads was highlighted during past earthquake events [1,2]. The employment of reinforcing bars to construct earthquake resistant partially grouted masonry structures has been widely investigated. Manos et al. $[3,4]$ tested partially reinforced piers with different reinforcing schemes. For the tested piers with a height over length ratio equal to 1 and horizontal reinforcing ratio values larger than $0.085 \%$, the flexural response together with the rather ductile plastic rotation response at the bottom of the wall, similar to a plastic-hinge mechanism. Additionally, some of the specimens exhibited extensive compressive failures on the compression zone. Other researchers [5, $6]$ investigated the influence of the horizontal shear reinforcement in partially grouted masonry piers subjected to combined horizontal and vertical loads. It was observed that shear reinforcement not only provided additional resistance, but also improved the post-cracking performance. Recent studies investigate the behavior of reinforced masonry walls using new clay units with the appropriate thermal properties in an effort to improve the structures energy consumption together with an acceptable structural performance [7, 8]. Again, the importance of bricks mechanical properties was noted as the deformation of walls appeared to be limited by the brittleness of the units, as toe crushing develops for some walls, leading also to a low dissipation of energy.

An ongoing research of Laboratory of Strength of Materials and Structures deals with partially grouted reinforced masonry walls constructed with a novel clay unit. A key issue in the construction of these walls is the masonry unit employed. The geometry of this new unit was defined using parametric numerical predictions taking into consideration not only the mechanical properties, but also parameters like thermal properties, production cost and ease of construction practice $[9,10]$. In this paper the in-plane behavior of ungrouted and partially grouted masonry wallets is discussed. Results are presented from tests of unreinforced masonry wallets or reinforced with horizontal rebars of different diameters, which are subjected to in-plane diagonal compression. The mechanical properties of all the employed materials are defined through testing. Following, numerical predictions of this measured in-plane behaviour are also included. All these results are presented and discussed focusing on the influence of the reinforcing arrangement in the overall in plane response.

\section{SPECIMEN CONSTRUCTION AND MATERIAL PROPERTIES}

The geometry of the employed clay unit is depicted in Figure 1. The basic mechanical properties of this unit were measured at the Laboratory. More specific, unit's compressive strength perpendicular to the bed joint and parallel to the bed joint are measured by compression test according to EN772-1 [11]. The proposed reinforced masonry system uses the construction technique of thin mortar joint. The mechanical properties of the mortar material used, were obtained by material testing according to EN1015-19 [12]. Additionally, tensile tests for the used reinforcing steel bars with diameter $6 \mathrm{~mm}$ and $8 \mathrm{~mm}$ were conducted. The above mentioned propertied are listed at table 1 and table 2 .

The used vertically perforated units with nominal dimensions length $=210 \mathrm{~mm}$, height $=240 \mathrm{~mm}$ and thickness $=300 \mathrm{~mm}$ had properly shaped to form two horizontal channels in order to embody the horizontal reinforcement (figure 1). Additionally, vertical holes are formed between the clay units used for the vertical reinforcing bars.

All specimens were built by builders following the relevant prototype work conditions. The constructed specimens (1340mm by $1340 \mathrm{~mm}$ and a thickness of $300 \mathrm{~mm}$ ) were tested under diagonal compression. The used experimental set up are depicted in figure 2. This simple loading scheme to study the in-plane performance of masonry panels is specified by ASTM 
E519-15 [13] and by RILEM Technical Recommendations for "Testing and Use of Construction Materials" [14].

\begin{tabular}{ll}
\hline Brick unit \\
\hline $\begin{array}{l}\text { mean compressive strength perpen- } \\
\text { dicular to bed joints }\left(\mathrm{f}_{\mathrm{b}}\right)\end{array}$ & $8.12 \mathrm{MPa}$ \\
$\begin{array}{l}\text { mean compressive strength parallel } \\
\text { to bed joints }\left(\mathrm{f}_{\mathrm{b}, \mathrm{h}}\right)\end{array}$ & $2.73 \mathrm{MPa}$ \\
\hline Mortar & \\
\hline compressive strength $\left(\mathrm{f}_{\mathrm{m}}\right)$ & $13.47 \mathrm{MPa}$ \\
flexural strength $\left(\mathrm{f}_{\mathrm{mt}}\right)$ & $2.80 \mathrm{MPa}$ \\
\hline
\end{tabular}

Table 1: mechanical properties of masonry materials used.

\begin{tabular}{lllll}
\hline $\begin{array}{l}\text { steel bar's } \\
\text { diameter }\end{array}$ & $\begin{array}{l}\text { yield stress } \\
(\mathrm{MPa})\end{array}$ & $\begin{array}{l}\text { ultimate stress } \\
(\mathrm{MPa})\end{array}$ & $\begin{array}{l}\text { yield } \\
\text { strain }\end{array}$ & $\begin{array}{l}\text { ultimate } \\
\text { strain }\end{array}$ \\
\hline D6mm & 605 & 650 & $3.00 \%$ o & $4 \%$ \\
D8mm & 550 & 657 & $2.75 \%$ & $15 \%$ \\
\hline
\end{tabular}

Table 2: mechanical properties of steel reinforcing bars
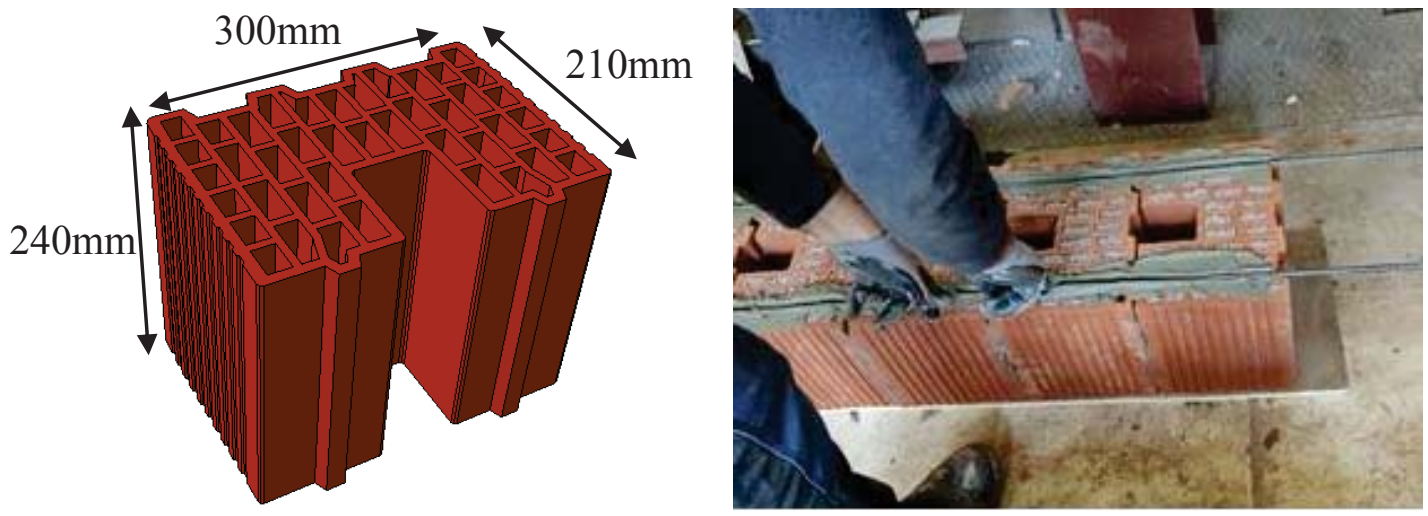

Figure 1: The geometry of the novel brick unit (left) and the employed of horizontal bars (right)
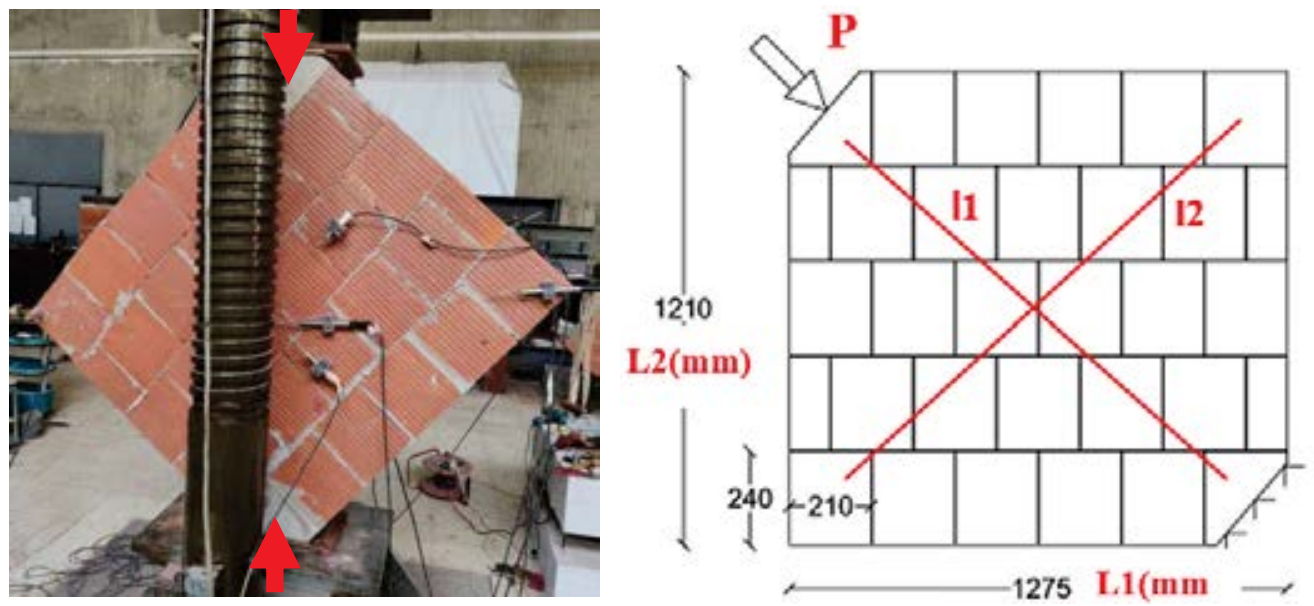

Figure 2: Experimental set-up (left) and the employed of horizontal bars (right) 
The vertical compressive load was monotonic and was applied at a relative slow rate being measured by a load cell. Displacement transducers were also used to measure the vertical and horizontal variation of the length of the two main diagonals at both facades of the loaded specimen. By utilizing these displacement transducers, the variation of the diagonal lengths was monitored together with the variation of the applied vertical load throughout the whole of the loading sequence employing an automatic data recording acquisition system. The observed performance for each tested specimen is presented in section 3 in terms of the variation of the equivalent shear stress versus the corresponding shear strain, obtained as described before.

All measurements were used to obtain the performance of each specimen in terms of the variation of the equivalent shear stress $(\tau \mathrm{s})$ versus shear strain $(\gamma)$ calculated through equations 1 and 2, as is described in ASTM E519-15 [13]. Each specimen was designed to be tested under diagonal compression along one of its main diagonals having a concrete block at the top and bottom corner of the vertical diagonal of each specimen in order to facilitate the application of the compressive diagonal load (fig. 3).

$P$ : the applied vertical load.

$$
\begin{aligned}
& \tau s=(0.707 * P) /[0.5 *(L 1+L 2) * t] \\
& \gamma=|\delta l 1| / l 1+|\delta l 2| / l 2
\end{aligned}
$$

L1 and L2: the length of the sides of the wallet as indicated in figure 2.

11 and 12 : the length of the vertical and horizontal diagonals the variation of which is monitored with displacement transducers attached on the brick façade of the wallet as indicated in figure 2.

$\delta l 1$ and $\delta 12:$ the variation of the relevant lengths $l 1$ and $l 2$ as they occur during the variation of the applied load $(P)$.

$t$ : the thickness of the masonry panel (neither the thickness of the thermo-insulating attachment nor the thickness of the adhesive mortar are included).

\section{EXPERIMENTALLY OBSERVED BEHAVIOR}

The observed diagonal compression performance of the tested specimens with or without horizontal reinforcing bars is presented and discussed in terms of the variation of the equivalent shear stress $(\tau \mathrm{s})$ versus shear strain $(\gamma)$ (equations 1 and 2 ) together with the observed damage. Firstly, the performance of the unreinforced wallets is given. Figure 4 (right) depicts the observed performance of the unreinforced masonry wallet without any reinforcement, which represents the control specimens. As can be seen the shear strength value is of the order of $0.56 \mathrm{MPa}$ and the equivalent shear-stress versus shear stain variation characterizes this performance as being rather brittle. At the same figure (4a) the formation of a typical diagonal tension crack characterizes the observed mode of failure.
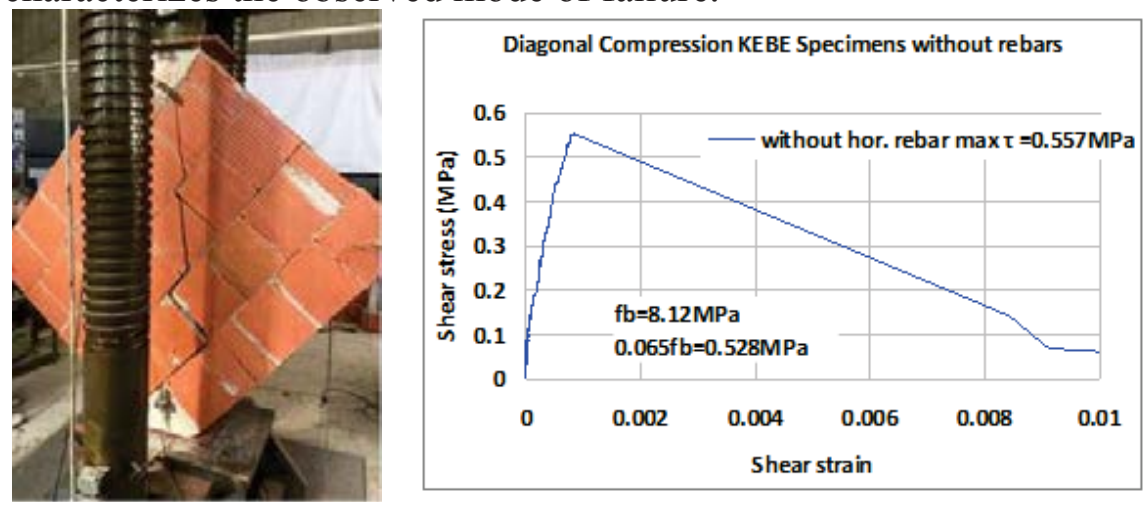

Figure 3: Damage pattern of bare wallet (left) and its response in terms of shear stress versus shear strain (right) 
Following, the response of the tested specimens with horizontal reinforcing bars is presented. Figure 4 depicts the observed damage and the variation of the equivalent shear stress $(\tau s)$ versus shear strain $(\gamma)$ (equations 1 and 2) for a specimen with 2 horizontal bars of diameter $6 \mathrm{~mm}$ at each bed joint. Figure 5 depicts the observed damage and the variation of the equivalent shear stress versus shear strain for a specimen with 2 horizontal bars with diameter of $8 \mathrm{~mm}$ at each bed joint. As can be seen the shear strength value for the reinforced specimens is slightly increased. The formation of a typical diagonal tension crack characterizes the observed mode of failure for these specimens.
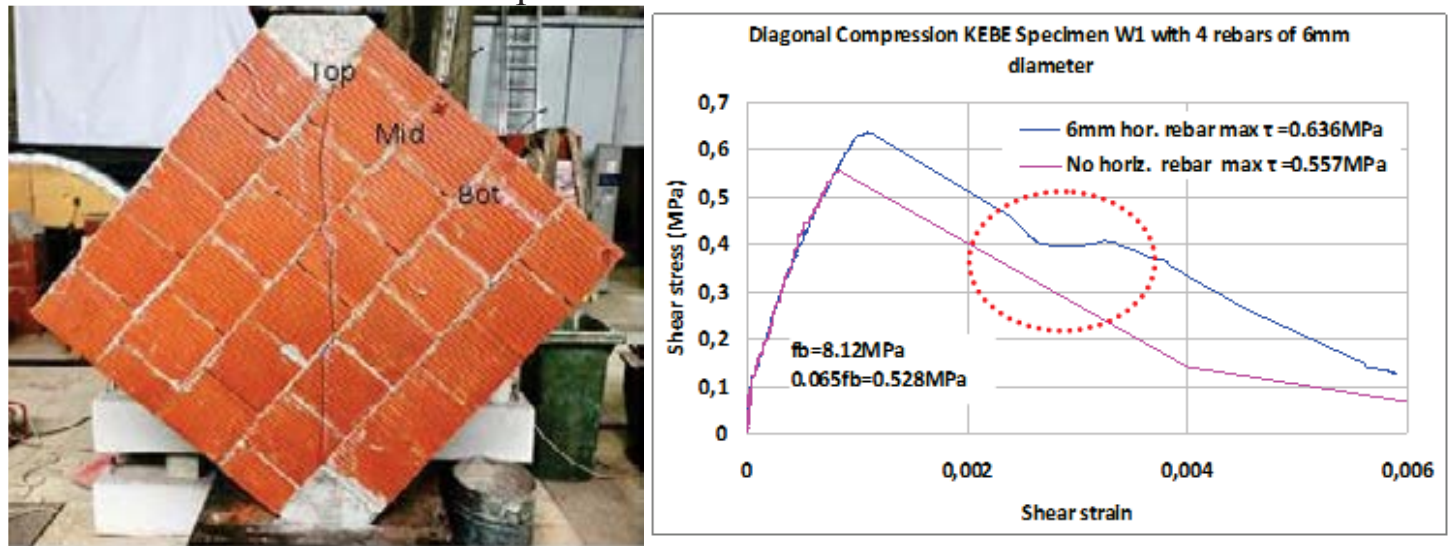

Figure 4: Damage pattern of reinforced wallet with D8mm reinforcing bars and its response in terms of shear stress versus shear strain (right)
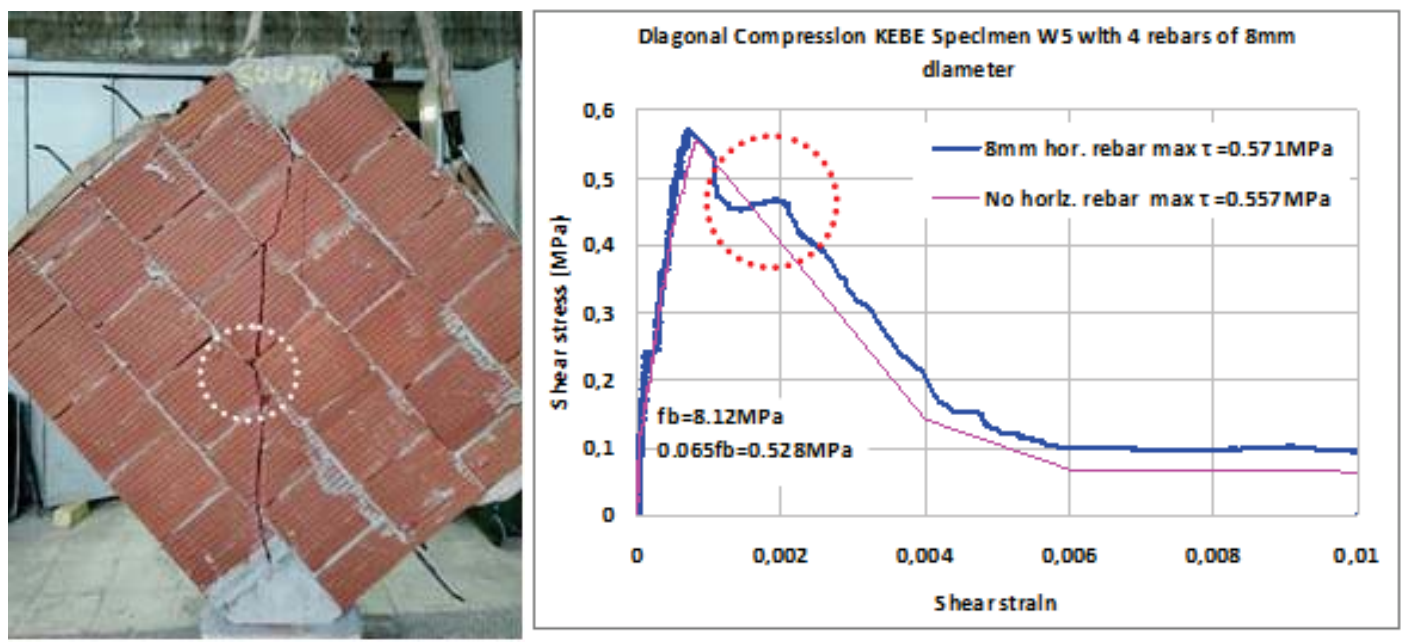

Figure 5: Damage pattern of reinforced wallet with D8mm reinforcing bars (left) and its response in terms of shear stress versus shear strain (right)

\section{NUMERICAL MODELING}

Three-dimensional finite element numerical models were formed, adopting a macro modeling approach with a homogenized material obeying the Concrete Damaged Plasticity (CDP) constitutive law for the masonry, that can satisfactorily represent the behaviour of brittle materials, like concrete or masonry, with different stress - strain laws for compression and tension. The numerical model resembling the unreinforced wallet was calibrated in order to capable follow the behavior observed at the laboratory. All the parameters used for the constitutive law are listed at table 3 . The geometry and details of the numerical model are depicted in figure 6. 


\begin{tabular}{|l|l|l|l|l|l|}
\hline \multicolumn{4}{|l|}{ Concrete Damaged Plasticity - material model assigned to masonry panel } \\
\hline Elastic properties & Compressive behavior & Tensile behavior \\
\hline $\begin{array}{l}\text { Young's } \\
\text { Modulus (MPa) }\end{array}$ & 4000 & $\begin{array}{l}\text { Yield } \\
\text { stress MPa }\end{array}$ & $\begin{array}{l}\text { Plastic } \\
\text { stain }\end{array}$ & $\begin{array}{l}\text { Yield stress } \\
\text { MPa }\end{array}$ & $\begin{array}{l}\text { Plastic } \\
\text { stain }\end{array}$ \\
\hline Poisson's ratio & 0.15 & 3.60 & 0 & 0.48 & 0 \\
\hline \multicolumn{2}{|l|l|l}{} & 0 & 0.01 & 0 & 0.01 \\
\hline
\end{tabular}

Table 3: Parameters of CDP constitutive law for masonry material

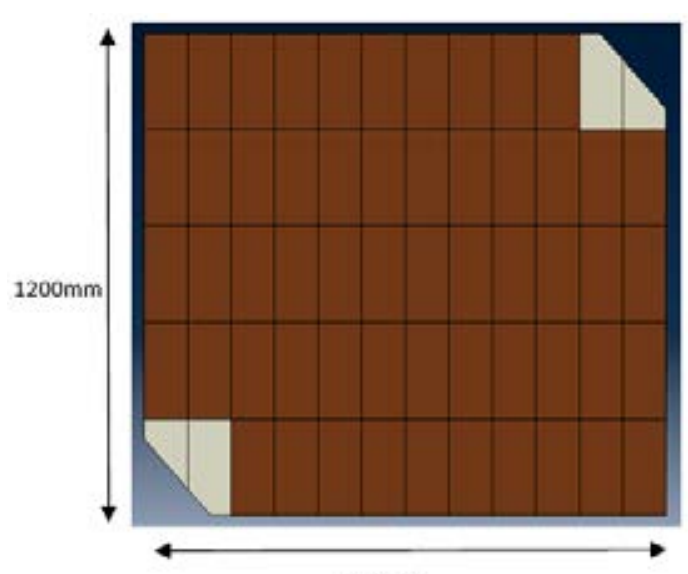

$1290 \mathrm{~mm}$

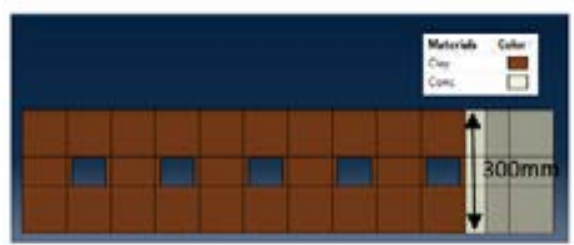

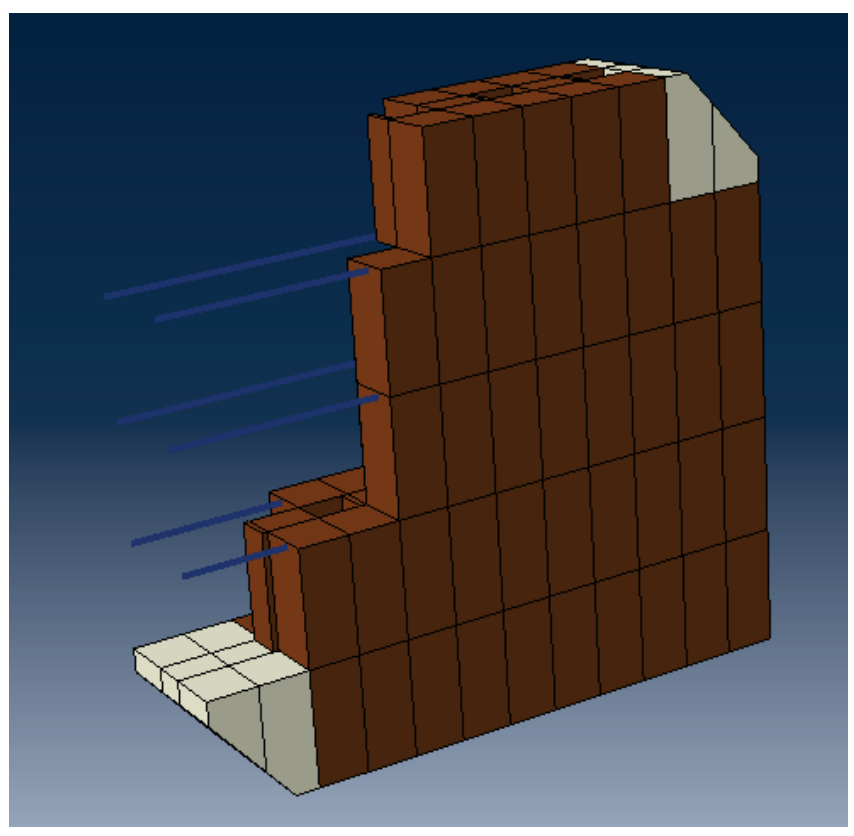

Figure 6: Numerical model. Front view and top view (left) and 3D view of the model with the embedded reinforcing steel bars (right)

The damaged pattern of the unreinforced wallet's numerical model is depicted in figure 7 together with the comparison of shear stress - shear strain response with the corresponding tested specimen. A very good agreement is observed both in the stress - strain response and in the damage pattern observed.
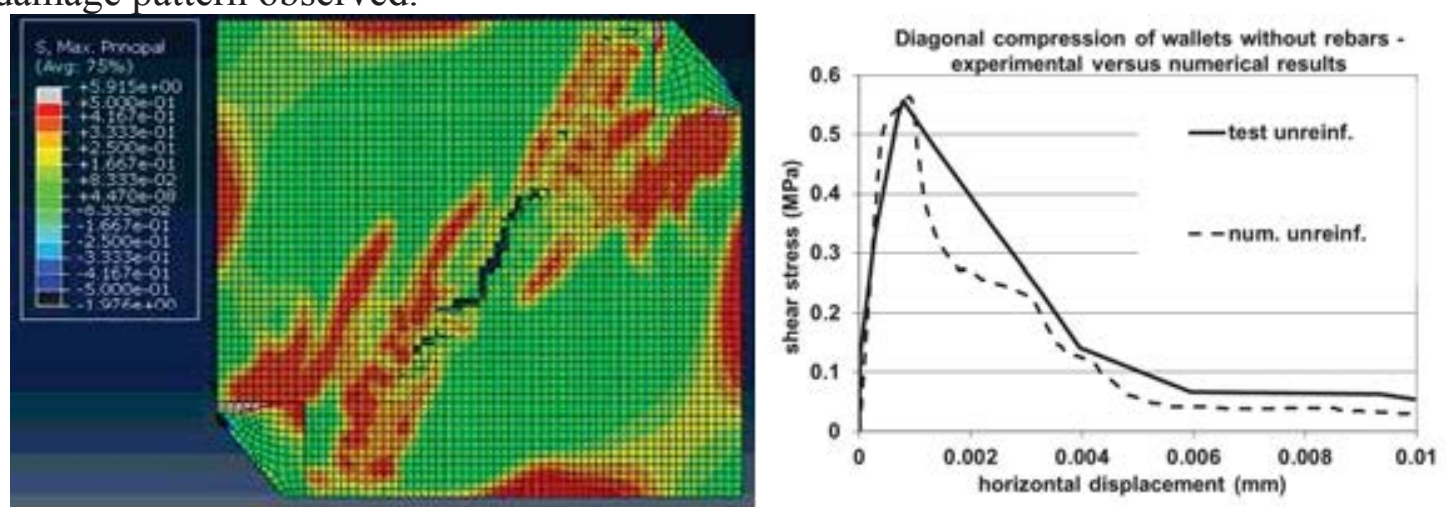

Figure 7: Maximum principal stresse $(\mathrm{MPa})$ and damage pattern of unreinforced numerical model at the step of maximum load (left) and its response in terms of shear stress versus shear strain (right)

Following, in the previous model horizontal reinforcing bars are added as shown in figure 6 with wire elements. The reinforcing bars are of diameter $6 \mathrm{~mm}$ or $8 \mathrm{~mm}$ as in the tested specimens. These bars are assigned with an elasto-plastic material law obtained by material testing 
(section 2). A perfect bond between rebars and the masonry panel is assumed. The damaged pattern of the numerical model and a comparison of shear stress - shear strain response with the corresponding tested specimens is shown in figure 8 and 9 for the model with horizontal bars with diameter $6 \mathrm{~mm}$ and $8 \mathrm{~mm}$ respectively. In general, a good agreement is observed both in the stress - strain response and in the damage pattern. Additionally, the developed axial stresses of the horizontal rebars are depicted in figure 10 at the step of maximum load for both reinforced models, in an effort to explain the contribution of the horizontal reinforcing bars in the overall response.
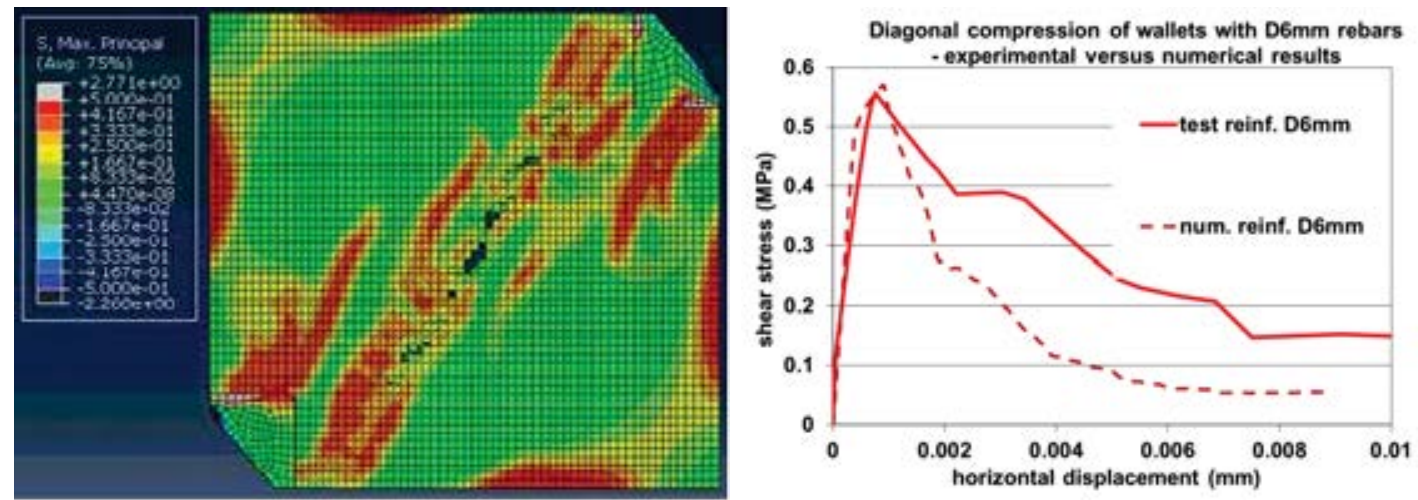

Figure 8: Maximum principal stresses (MPa) and damage pattern of reinforced with D6mm horizontal bars numerical model at the step of maximum load (left) and its response in terms of shear stress versus shear strain (right)
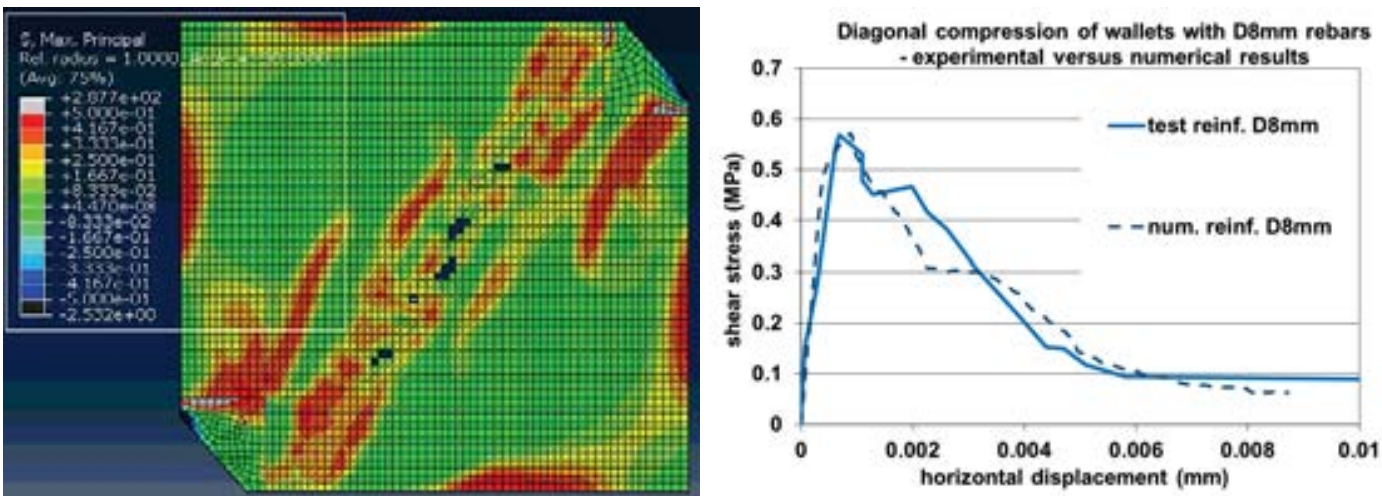

Figure 9: Maximum principal stresses $(\mathrm{MPa})$ and damage pattern of reinforced with $\mathrm{D} 8 \mathrm{~mm}$ horizontal bars numerical model at the step of maximum load (left) and its response in terms of shear stress versus shear strain (right)
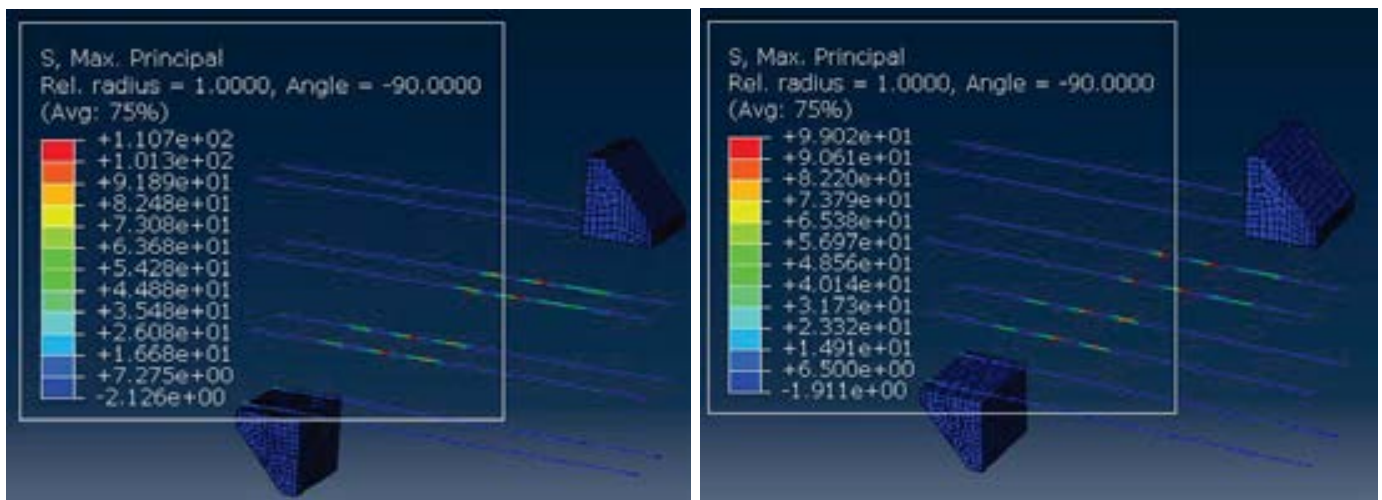

Figure 10: Developed axial stresses (MPa) of reinforcing bars at the step of maximum load for D6mm bars (left) and D8mm bars (right) 


\section{DISCUSSION}

Figure 12 depicts the response in terms of equivalent shear stress versus shear strain for unreinforced and reinforced with horizontal reinforcing steel bars with diameter either $6 \mathrm{~mm}$ or $8 \mathrm{~mm}$. The corresponding numerical predictions are also shown in the same figure. In all cases it is clear that there is no remarkable increase of shear strength due to the reinforcing steel bars. Over the literature there are studies reporting similar observations by diagonal compression test either on reinforced masonry wallets [15] or on strengthened wallets with steel bars mounted near masonry's surface [16]. This is explained by the fact that till the maximum load, reinforcement's stresses are not great. When the non-linear behavior occurs and masonry's cracks are widening the reinforcing bars develop greater stress. Thus, the existence of horizontal reinforcing bars seems to improve the post peak response leading to a less brittle declining brunch.

The shear strength is highly affected by the clay unit's compressive strength as the diagonal cracking propagates through the clay units. This mode of failure is predicted in Eurocode 6 [17] as the shear strength is prevailed by an upper limit of $0.065^{*} \mathrm{fb}$ (units' mean compressive strength). In the examined case this limit is calculated $0.528 \mathrm{MPa}$, pretty close to the shear strength values obtained by the diagonal compression tests.

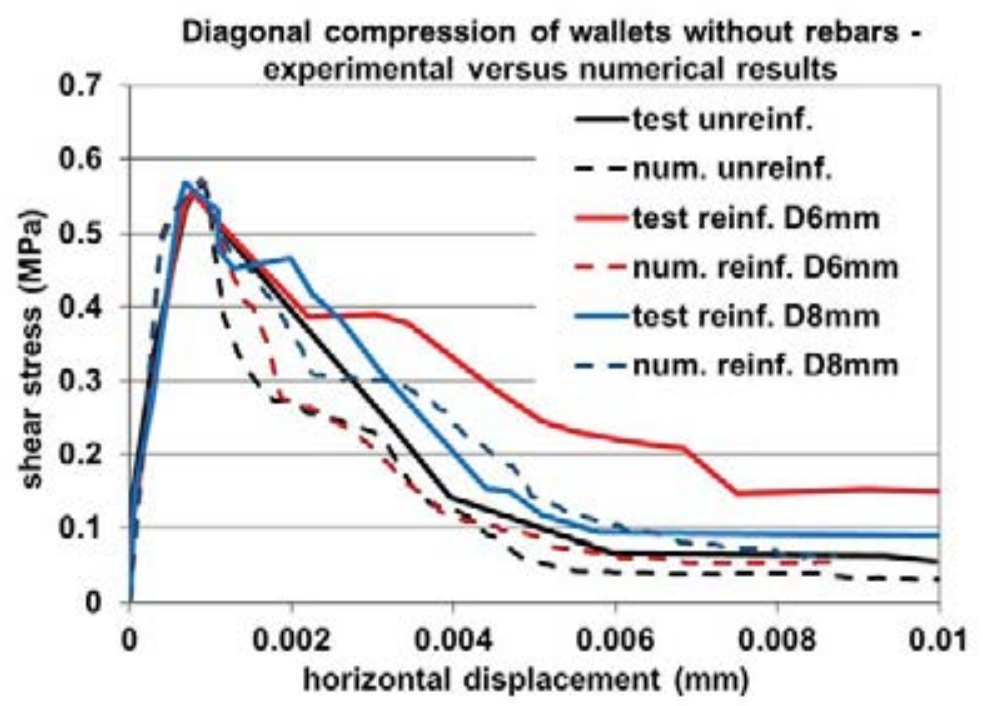

Figure 11: Response of both tested specimens and numerical models for unreinforced and reinforced configuration

\section{CONCLUSIONS}

The behavior of reinforced masonry wallets under diagonal compression is discussed here, mainly focusing on the contribution of the horizontal reinforcing bars in the overall wallet's response. Apart from the experimental observations, numerical models were developed using all the available information about the mechanical properties of the materials used in an effort to numerically reproduce the behavior observed at the laboratory. The main conclusions are enlisted below:

- The horizontal reinforcing bars are not clearly increase masonry's shear strength, but they contribute for the increase on the ductility.

- The observed damage pattern of the diagonal cracking does not change when horizontal reinforcing bars are added and it is directly linked with the compressive strength of clay units used. 
- The developed numerical models, after calibrated with the unreinforced specimen's response, can satisfactorily capture the observed behavior of reinforced masonry wallets both in terms of shear stress - shear strain response, but also in the damage pattern.

\section{ACKNOWLEDGEMENTS}

All materials for the construction of the specimens were provided by "KEBE S.A. (Northern Greece Ceramics)". Part of the aforementioned research "Innovative construction system of reinforced masonry with anti-seismic, thermal-insulating and environmental friendly characteristics (TheSeisMas)" has been co-funded by Greece and European Union through the Operational Program "Erevno - Dimiourgo - Kainotomo" (project code: T1EDK-03314) which are gratefully acknowledged.
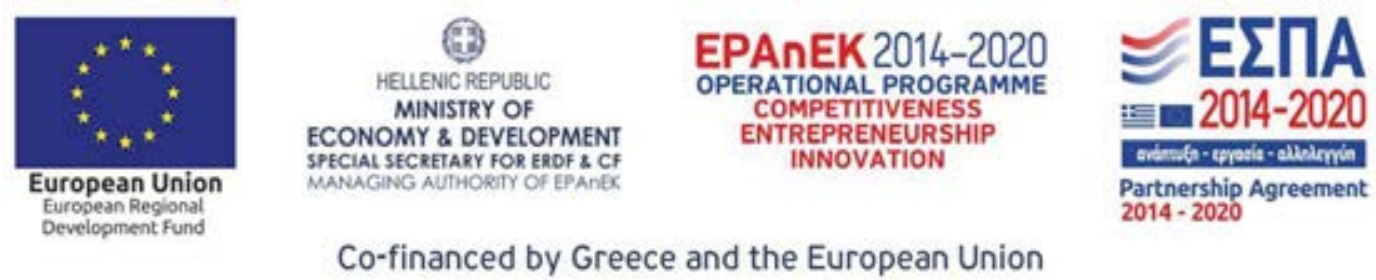

\section{REFERENCES}

[1] Manos G (2011), "Consequences on the urban environment in Greece related to the recent intense earth-quake activity", Int. Journal of Civil Engineering and Architecture, Volume 5, No. 12 (Serial No. 49), pp. 1065-1090.

[2] Manos G.C. (2020) "The 30th of October Samos-Greece Earthquake. Issues relevant to the protection of structural damaged caused by strong earthquake ground motions", Journal Architecture and Engineering, Volume 5 Issue 4, https://aej.spbgasu.ru/index.php/AE, DOI: 10.23968/2500-0055-2020-5-4-03-17

[3] G.C. Manos, L. Kotoulas, L. Melidis, K. K. (2019). Partially grouted reinforced brick masonry wall specimens made in Greece subjected to in-plane seismic loadingQ experimental observations and numerical prediction. 13th North American Masonry Conference.

[4] Manos, G. C., Kotoulas, L., Melidis, L., \& Katakalos, K. (2019). Partially grouted reinforced masonry piers under seismic-type in-plane loads. Experimental measurements and non-linear numerical simulations. COMPDYN Proceedings, 1, 252-268. https://doi.org/10.7712/120119.6917.19257

[5] Calderón, S., Sandoval, C., \& Arnau, O. (2017). Shear response of partially-grouted reinforced masonry walls with a central opening: Testing and detailed micro-modelling. Materials and Design, 118(January), 122-137. https://doi.org/10.1016/j.matdes.2017.01.019

[6] K. C. Voon, J. M. I. (2006). Experimental In-Plane Shear Strength Investigation of Reinforced Concrete Masonry Walls. Journal of Structural Engineering.

[7] Mosele, F., \& Da Porto, F. (2011). Innovative clay unit reinforced masonry system: Testing, design and applications in Europe. Procedia Engineering, 14, 2109-2116. https://doi.org/10.1016/j.proeng.2011.07.265 
[8] Loureçno, P. B., Vasconcelos, G., Medeiros, P., \& Gouveia, J. (2010). Vertically perforated clay brick masonry for loadbearing and non-loadbearing masonry walls. Construction and Building Materials, 24(11), 2317-2330. https://doi.org/10.1016/j.conbuildmat.2010.04.010

[9] Kotoulas, L., Manos, G. C., Melidis, L., Katakalos, K., \& Manolis, G. (2019). Unreinforced masonry materials under axial compression or four-point flexure. Laboratory measurements and numerical simulations. COMPDYN Proceedings, 1, 345-358. https://doi.org/10.7712/120119.6923.19346

[10] Manos, G. C., Melidis, L., \& Katakalos, K. (2020). PARTIALLY REINFORCED MASONRY PIERS UNDER SEISMIC-TYPE LOADS. MEASUREMENTS AND NUMERICAL SIMULATIONS. 17th World Conference on Earthquake Engineering.

[11] EN 772-1:2011 - Methods of test for masonry units Part 1: Determination of compressive strength.

[12] EN 1015-11:2019 - Methods of Test for Mortar for Masonry - Part 11: Determination of flexural and compressive strength of hardened mortar.

[13] ASTM E519-15 (2015) Standard test method for diagonal tension (shear) in masonry assemblages. American Society for Testing Material

[14] RILEM LUMB6 (1994) Diagonal tensile strength tests of small wall specimens (1991). Rilem recommendations for the testing and use of constructions materials. RILEM, pp 488-489.

[15] Haach, V. G., Vasconcelos, G., \& Lourenço, P. B. (2014). Study of the behaviour of reinforced masonry wallets subjected to diagonal compression through numerical modelling. 9th International Masonry Conference 2014, 1-11.

[16] Ismail, N., Petersen, R. B., Masia, M. J., \& Ingham, J. M. (2011). Diagonal shear behaviour of unreinforced masonry wallettes strengthened using twisted steel bars. Construction and Building Materials, 25(12), 4386-4393. https://doi.org/10.1016/j.conbuildmat.2011.04.063

[17] EN1996-1-1:2005 Eurocode 6 - Design of masonry structures - Part 1-1: General rules for reinforced and unreinforced masonry structures 